\title{
EUROPE, AMERICA AND THE “UNITY” OF INTERNATIONAL LAW
}

\author{
Joost Pauwelyn \\ (Duke University School of Law)
}

Panel on The Implications of "Europeanization" of Public International Law for the Unity and Coherence of International Law, Conference on "Europeanisation" of Public International Law: The Status of International Law in the EU and its Member States, Amsterdam, September 2, 2005

Preliminary Draft August 2005

\section{The Question, And What Asking It Implies For Europe}

Is international law "Europeanized"? If so, what are the implications of such "Europeanization" for the unity and coherence of international law? To the neutral observer, international law could be Europeanized on at least two levels:

(1) Europe may have a particular impact on, or approach to, international law that distinguishes it from the rest of the world;

(2) European courts either in Luxembourg or the member states, or both, could be receiving, applying and interpreting international law in a manner that is different from non-European courts or international tribunals.

Although the focus of this conference seems limited to (2), that is, how European judiciaries receive international law, the broader question of (1), which extends to European policy-makers, bureaucrats and society at large, is equally important.

At both of these levels (European courts v. European society), the link between the Europeanization of international law, on the one hand, and the debate on unity or fragmentation of international law, on the other, is readily made: 
(1) If European courts apply and interpret international law in one way, the risk arises that other courts - be they international tribunals or national courts outside Europe -- take a different view. This could be seen as a threat to the unity of international law (Section II).

(2) Similarly, a distinct European approach to international law raises the specter of fragmentation, in particular, a European versus an American view of international law (Section III).

The fact that we Europeans even ask the question - i.e., does a European model of international law threaten the unity of the international system? -- unearths a more fundamental underlying current in European international law circles: A post-modern anxiety to openly defend and export a "European" model of international law. ${ }^{1}$ This reluctance is fed by the critical legal scholar's charge that "[i]nternational law is a European tradition ... [which] imagines itself as universal" ${ }^{2}$ and fears of neo-colonialist reproaches especially by developing countries, of the kind that Europe would normally direct against so-called American unilateralism or imperialism. ${ }^{3}$

\footnotetext{
${ }^{1}$ On this European model, see Jeremy RifKin, The European Dream, How Europe's Vision of the FUTURE IS QUIETLY ECLIPSING THE AMERICAN DREAM (2004).

${ }^{2}$ Martti Koskenniemi, International Law in Europe: Between Tradition and Renewal, 16 EJIL 2005 113124, at 113.

${ }^{3}$ For a perfect anecdote confirming such European fears, see PHILIPPE SANDS, LAWLESS WoRLD, AMERICA AND THE MAKING AND BREAKING OF GLOBAL RULES (2005), recounting his visit to Tehran University and talk there about the Pinochet case. Sands decided to simply recount the facts of the case for fear that "the Court's decision not to recognize Pinochet's claim to immunity would be taken as a further example of the colonialist/imperialist tendency endemic in British culture, including its legal culture, and an inability to refrain from meddling in the internal affairs of Chile, another state”(at 223). To Sands' great surprise, however, in students' reactions to the talk, "criticism was directed not at the House of Lords but at me, why did I not embrace the case as a great moment for international law and the cause of human rights? ... It was striking that international law had provided a common language to explore complex moral and political issues faced by just about every country in the world" (at 224). Similarly, talk about human rights or environmental protection in the world of international trade is too often and easily portrayed as a Northern hegemonic agenda imposed on poor Southern countries. But clearly, even if such talk is at times thinly disguised protectionism, it is not as if developing countries are waiting to violate human rights or have a value-system or unstoppable urge to torture or enslave their people and to pollute their surroundings.
} 
In the United States, in contrast, defense of national interests and a US model of international law are unabashedly pursued. ${ }^{4}$ The fact that the United States, including its courts, might thereby exert a distinct influence on international law is seen as a plus, even a goal, not a threat to the "unity" of international law. ${ }^{5}$ Witness recent discussions in the United States on the Alien Tort Statute $e^{6}$ and the application of international law by the US Supreme Court. ${ }^{7}$ Both debates center on the extent to which international law encroaches on US sovereignty. That “American” applications of international law might threaten the "unity" of international law is never mentioned. ${ }^{8}$

\footnotetext{
${ }^{4}$ See JACK GoldSMith AND ERIC Posner, The Limits of InTERNATIONAL LAW (2005), whose theory is that "international law emerges from states acting rationally to maximize their interests, given their perception of the interests of other states and the distribution of state power" (at p. 3).

${ }^{5}$ Even so-called internationalists within the US legal academy argue for US commitment to international law as a means to promote US values and hegemony, see Leila Nadya Sadat, An American Vision For Global Justice: Taking The Rule Of (International) Law Seriously 4 WASHINGTON UNIVERSITY GLOBAL StUDIES LAW REVIEW (2005) 328 at 331 ("the United States needs to take its commitment to the rule of law to the global stage, thereby playing to American strengths, enhancing American legitimacy and moral authority, and perpetuating the leadership role that the United States has historically exercised in the conduct of international affairs. As the hegemon presiding over — and benefiting the most from - the global economy, the United States has both a vital interest in maintaining the stability of that system and a responsibility to ensure that the system is fair").

${ }^{6}$ When, for example, the scope of the Alien Tort Statute is discussed in US legal academia, the pros and cons of American courts enforcing international law at the request of aliens and mostly against aliens center around the language and history of the statute, US federalism and constitutional law and US national interests in the world, not the risk of US courts expressing a distinct view of international law and thereby disproportionately contributing to the future of international law and threatening its "unity".

${ }^{7}$ See, for example, Thomas H. Lee, The U.S. Supreme Court as Quasi-International Tribunal: Reclaiming the Court's Original and Exclusive Jurisdiction over Treaty-Based Suits by Foreign States against States, 104 COLUMBIA LAW REVIEW (forthcoming), arguing that the US Constitution grants original jurisdiction to the US Supreme Court for claims by foreign countries against individual US states and invoking as one of the main arguments in favor of such jurisdiction the prospect that the US Supreme Court could thereby become the primus inter pares of international tribunals ("Whether or not one views this judicial globalization as progress, it is surely inevitable, and it is equally certain that for the U.S. Supreme Court to sit on the sidelines as it happens is self-defeating”). Contrast this to Piet Eeckhout, Judicial Enforcement of WTO law in the European Union, 5 JIEL 93 (2002), pointing out, as an argument to deny direct effect, that by giving direct effect to WTO law, the ECJ could easily become the most important court for the interpretation of the WTO and in doing so could in fact come into competition with the WTO Appellate Body.

${ }^{8}$ At most, the openness, for example, of the US Supreme Court to enforce certain international norms under the Alien Tort Statute is seen as an attempt by the US judiciary to amplify its powers as against other domestic actors. See Julian Ku and John Yoo, Beyond Formalism in Foreign Affairs: A Functional Approach to the Alien Tort Statute, University of California at Berkeley School of Law, Boalt Hall Public Law and Legal Theory Research Paper Series, Research Paper No. 652141 (2005), at 2 ("We believe that the Court was reluctant to end federal judicial participation in the development and enforcement of CIL for unstated functional, policy, or pragmatic reasons, which have also been unexplored in the academic debate").
} 
Along similar lines, Europe ought to overcome its post-modern anxiety, realize that the "European model" has much to contribute to the future development and shaping of international law and without regrets pursue a "European” agenda based on European values and interests. ${ }^{9}$ Frontal attacks on US foreign policy, including a Europe-wide position against a particular candidate in US Presidential elections, have proven to be counter-effective. The better approach is to engage the US with equal weapons, that is, with a positive European agenda steadfastly pursuing European values and interests. For Europe to define and defend such European agenda will, in the long term, strengthen rather than undermine the unity of international law. For one thing, it will remind us how much Europe and America continue to have in common both in terms of values and the challenges they face. ${ }^{10}$

Crucially, however, any such European agenda must avoid the extremes of European idealism, or what I will call European normativism. Of equal importance, it must skirt the excesses of American realism or what I will refer to as a purely transactional approach to international law. Taking both of these extremes seriously -- that is, Europeans taking American critiques of international law seriously and Americans honestly examining the "European dream" -- and subsequently finding a middle ground between such realism and idealism, the transactional and normative approach to international law, in short, the American and European model, is one of the greatest challenges for us international lawyers in the $21^{\text {st }}$ century. We must move beyond the shouting games over the International Criminal Court and the Kyoto Protocol ${ }^{11}$, and end the débat des sourds between Kantian cosmopolitans based in Europe and the now

\footnotetext{
${ }^{9}$ As Koskenniemi puts it (ibid., at 115): "The fact that international law is a European language does not even slightly stand in the way of its being capable of expressing something universal. For the universal has no voice, no authentic representative of its own. It can only appear through something particular; only a particular can make the universal known. A danger and a hope are involved. The danger is that of mistaking one's preferences and interests for one's tradition - and then thinking of these as universal, a mistake we Europeans have often made".

${ }^{10}$ Even the late Jacques Derrida, shortly before his death, pointed at Europe's return to the tradition of international law and institutions as the world's best hope (G. Borradori, Philosophy in Times of Terror, Conversations with Jurgen Habermas and Jacques Derrida (2003), at 116-119). For a view stressing the communalities between Europe and the US, see Timothy Garton Ash, FreE WORLD (2005).

${ }^{11}$ For a stimulating example, see Jutta Brunnee, The United States and International Environmental Law: Living with an Elephant, 15 EJIL (2004) 617 and most of the other articles in that issue's Symposium on the United States and International Law.
} 
predominant conservative international legal academy in the United States. This paper is a modest attempt in that direction.

\section{Is The Application Of International Law By European Courts A Threat To The Unity Of International Law?}

This Section does not discuss the appropriateness of European courts (be it the ECJ or domestic courts) applying or giving “direct effect” to public international law, be it customary international law, WTO law, the ECHR or the Biodiversity Convention. Doing so raises serious questions of democratic legitimacy (especially if international law is automatically supreme to all domestic law) and balance of powers, first, internally between the judiciary and the legislative/executive branches of government and, second, externally between countries giving direct effect to international law and those that do not. ${ }^{12}$ Rather, this Section assumes that European courts do refer to international law be it through direct application or the method of "consistent interpretation" of domestic law with international law - and queries the impact of such reference on the unity of international law.

The perspective adopted in this Section is, therefore, a purely international one, that is, from the perspective of international law, is the risk of inconsistent interpretations a valid reason for domestic courts and/or the ECJ not to refer to public international law?

\footnotetext{
${ }^{12}$ Along those lines, I have expressed doubts about giving direct effect to WTO law in domestic courts. See Joost Pauwelyn, The Transformation of World Trade, 104 MiCHIGAN LAW REVIEW (2005:1, forthcoming), available at http://www.law.duke.edu/fac/pauwelyn/pdf/world trade_6nov04.doc (describing the lack of direct effect of WTO law in domestic courts as an "exit option" for WTO members which enabled the strengthening of the WTO dispute process, limits the need for "voice”, facilitates political agreement on new WTO rules and offers a democratic safety valve) and Joost Pauwelyn, A Typology of Multilateral Treaty Obligations: Are WTO Obligations Collective or Bilateral in Nature? 14 EJIL (2003) 907-951, especially at 948 (arguing that WTO provisions are bundles of bilateral relationships, not collective or erga omnes partes obligations; as a result, flexibility in their implementation and remedies scheme is permissible and may actually operate as a democratic safety valve).
} 


\section{A more effective international law outweighs the risk of inconsistent interpretations}

At a most basic level, to argue that the application of international law by European courts threatens the unity of international law ${ }^{13}$ is like saying that the application of Dutch law by Amsterdam courts threatens the unity of Dutch law. Of course international law should applaud its application in European courts. It extends the relevance and impact of international law from the international to the domestic scene. As the domestic legal system is backed-up by a more effective enforcement mechanism, it also strengthens the implementation of, and compliance with, international law. From that perspective, the risk of inconsistent interpretations is only a side effect, a potential cost that is dwarfed by the immediate benefits of a more robust international law.

After all, what is the alternative? For European courts not to apply international law at all, because of the risk of inconsistent interpretations? Thus presented, one may be choosing between two evils: either (1) apply international law and risk inconsistent interpretations or (2) ignore international law altogether. ${ }^{14}$ In my view, however, from

\footnotetext{
${ }^{13}$ See, for example, in respect of the ECJ applying WTO law, A. Rosas, Annotation to C-149/96, Portugal v. Council 37 CMLR 797 (2000) at 812 ("Interpretations on individual provisions handed down by various national courts could pose serious problems for the overall system, notably as there is no possibility for national courts to obtain a ruling by the WTO bodies that are in charge of dispute settlement”); $\mathrm{M}$.

Bronckers and P-J Kuijper, The WTO in the European Court of Justice CMLR (2005, forthcoming) ("One must admit that serious practical problems may arise in relation to the coordination of interpretation. The lack of any equivalent for the preliminary ruling procedure in the WTO could lead to great inequality between the members of the organisation in the implementation of the WTO rules"); A. von Bogdandy, "Legal Equality, Legal Certainty, and Subsidiarity in Transnational Economic Law", in: A. von Bogdandy/P. C. Mavroides/Y. Mény (eds.), European Integration and International Co-ordination, 2002, 13-37, at $30 \mathrm{ff}$. (arguing that the risk of divergent judicial interpretations is one of legal equality) and $\mathrm{M}$. Krajewski, Verfassungsperspektiven und Legitimation des Rechts der Welthandelsorganisation (WTO), 2001, at $63 \mathrm{ff}$. and 270 (pointing at the absence of a mechanism to settle discrepancies between WTO dispute rulings and national court rulings on WTO provisions as a reason to exclude direct effect of WTO law in all members of the WTO).

${ }^{14}$ This reminds me of the choice that WTO panels must make: either (1) apply WTO law together with other international law (e.g. environmental or human rights treaties) and risk making the wrong or an inconsistent interpretation of those treaties, or (2) apply WTO law in a legal vacuum and completely ignore other international law. If one is a human rights activist, for example, should not the former approach be advocated? See Joost Pauwelyn, The Role of Public International Law in the WTO: How Far Can We Go?, 95 AJIL (2001) 535-578 and JoOst PAUWELYN, CONFLICT OF NORMS IN PUBLIC INTERNATIONAL LAW, HOW WTO LAW RELATES TO OTHER RULES OF INTERNATIONAL LAW (2003).
} 
the standpoint of international law ${ }^{15}$, the cost-benefit analysis is readily made: rather bolster the implementation and effectiveness of international law and accept the risk of contradictory interpretations, than live a life of complete neglect in the legal venues that matter the most (i.e., domestic courts).

With sovereignty concerns in mind, and to facilitate acceptance of international norms on as wide a base as possible, international law has always accepted a degree of discretion when it comes to its implementation in domestic law (witness the freedom of nations to adopt either a monist or a dualist approach). The risk of inconsistent interpretations fits within this long-recognized discretion.

To argue that, for unity's sake, the interpretation of international law should be the exclusive domain of international courts and tribunals is, therefore, more of a hegemonic project to defend the turf of international lawyers against the intrusion of domestic actors $^{16}$, than an agenda to defend international law as such. ${ }^{17}$ It reminds one of the human rights activist arguing against the application of human rights treaties by WTO panels $^{18}$, or of the ICJ judge crying foul at the creation of specialized international

\footnotetext{
${ }^{15}$ This calculus from a standpoint other than that of international law (e.g., looked at from the perspective of domestic law) may, of course, be different. Weighing concerns of democratic legitimacy and balance of powers pointed at earlier, one may well conclude not to give direct effect to international law. See supra note 12.

${ }^{16}$ When P.-J. Kuijper (EC Commission official and former Director at the WTO) emphasizes the existence of a distinct WTO dispute mechanism and the threat of inconsistent interpretations as arguments to deny direct effect of WTO law in the ECJ (see supra note 13), one could, indeed, be excused to think that by submitting such arguments he tries to protect the power of the EC Commission against ECJ interference, and to keep the WTO level (where the EC Commission enjoys extensive powers and discretion) distinct and separate from the domestic EC legal system (where the Commission is subject to more stringent checks and balances). The same could be said about A. Rosas' Annotation, supra note 13 (written at a time where he was still an EC Commission official, not an ECJ judge as he now is). Recall, however, that the present author is skeptical about giving direct effect to WTO law, but not because of an alleged risk of inconsistent interpretations (see note 12).

${ }^{17}$ See Martti Koskenniemi, Global Legal Pluralism: Multiple Regimes and Multiple Modes of Thought, Harvard Presentation, 5 March 2005, 5 ("Unity is a hegemonic project. It seeks the predominance of my perspective, my institution. Against this, we are accustomed to depicting the world - or some aspect of it as oppressively homogeneous, ruled by a totalizing logic of power, globalization, empire”).

${ }^{18}$ See supra note 14 . Although application of human rights by WTO panels would clearly bolster the impact of human rights, quite a number of human rights activists have, however, argued against such approach. They want to reserve "their" domain of human rights exclusively to human rights bodies and fear the hijacking of their turf by trade lawyers who, in their view, would interpret human rights with a free-trade bias.
} 
tribunals for fear that such tribunals may hold a different view on general international law and thereby undermine the unity of the system. ${ }^{19}$

2. The bright side of "judicial competition" and its prerequisites: Judicial curiosity, dialogue and tolerance

That reference to international law may occasionally lead to inconsistent rulings on the same question of international law is not necessarily the end of the system of international law. On the contrary, it may be an engine for reflection, refinement and further development of international law. After all, in domestic legal systems as well, different lower courts may issue inconsistent interpretations on the same question of domestic law and it often takes years or decades for the highest court to intervene, the court often waiting until the discussion has sufficiently matured.

The absence of a preliminary or advisory ruling system, linking domestic courts to the relevant international tribunal, may lack the clarity and hierarchical structure of the internal European system (where national courts of the member states can request preliminary rulings on questions of EC law from the ECJ). At the same time, the unstructured interaction between domestic and international courts, and domestic courts amongst themselves, avoids supremacies that are carved in stone and enables a healthy judicial competition in which the best interpretation is likely to surface (along the lines of "regulatory competition" or the "laboratory of ideas" tolerated, even encouraged, in the 50 states of the US).

In addition, preliminary references by national courts from, potentially, 190 countries to, for example, the ICJ or the WTO Appellate Body would risk long delays, overburdening those international tribunals and, perhaps most important of all, raise questions of democratic accountability and sovereignty far beyond those currently expressed against international organizations. Indeed, those international tribunals would then be viewed as some supreme court of appeals against even the highest domestic court, a sufficient

${ }^{19}$ See Judges Guillaume, Jennings. 
reason to speculate that countries like the United States would never accept such reference system.

Today’s multi-layered governance structure - national, international and transnational is of such complexity that clear-cut hierarchies have become illusive. ${ }^{20}$ In that sense, the messy interaction between domestic and international courts - with its inherent risk of contradiction -- may be a blessing rather than a curse. ${ }^{21}$ What is needed then to nurture this interaction between courts on issues of international law is not strict hierarchies or delineated reference systems, but an open and robust judicial dialogue premised on a minimum of judicial curiosity and tolerance toward other legal regimes and actors. ${ }^{22}$

As much as strict unity smells of hegemony (in our case, as pointed out earlier, international lawyers protecting their turf against domestic actors or specialized international tribunals), equally, self-contained fragmentation (here, refusal by courts to take account of other international rules or rulings) is often inspired by a superiority complex or hegemonic project. Closing one’s doors to international law -- as the ECJ arguably did in the 1972 Dyestuffs judgment or the GATT did in the 1990s Tuna/Dolphin cases -- can easily be interpreted as an attempt to give identity and autonomy to "my" regime as one that towers above all others. ${ }^{23}$

\section{Three techniques to avoid inconsistent interpretations}

Finally, the risk of truly divisive and lasting inconsistencies of interpretation can be mitigated, if not altogether avoided, by three commonly used techniques.

\footnotetext{
${ }^{20}$ See Gunther Teubner and Andreas Fischer-Lescano, Regime Collisions: The Vain Search for Legal Unity in the Fragmentation of Global Law, MichigAN JouRnAL OF INTERNATIONAL LAW 25 (2004), 999-1046.

${ }^{21}$ See in this respect Christian Joerges' theory of “deliberative supranationalism” to replace the current EU supremacy approach (Christian Joerges, Rethinking European Law's Supremacy: A Plea for a Supranational Conflict of Laws, on file with author).

${ }^{22}$ Even within the EC system such tolerance without strict rules is at play, especially between the ECJ and the member states' highest constitutional courts (see the Solange case law and J.H.H. Weiler's notion of "constitutional tolerance").

${ }^{23}$ See infra note 44.
} 
Firstly, one court (say, the ECJ) can refer to the rulings of other courts (say, the ICJ, the ECtHR or the WTO Appellate Body). For example, in Poulsen, Racke and Opel Austria (cases where the Luxembourg courts referred to customary international law) reference was made to ICJ judgments. In its relation to the ECHR, the ECJ has also been "careful to ensure that its case-law on fundamental rights conforms with the case-law of the European Court of Human Rights". ${ }^{24}$ Although such “reference” must not automatically imply “deference”, deviation ought to be rationally explained so as to enable and foster judicial dialogue (as the Appeals Chamber of the International Criminal Tribunal for the Former Yugoslavia did when disagreeing with the ICJ's standard of control required for state attribution).

Secondly, another tool to avoid inconsistent interpretations is for European courts to seek expert advice on the relevance and meaning of public international law and other treaties, preferably from the bodies in charge of those other treaty regimes. Along those lines, WTO panels, for example, seek the advice of other international organizations and secretariats on a regular based (e.g., the WHO Codex Alimentarius Commission, WIPO or the World Customs Organization). ${ }^{25}$

Thirdly, where national courts of one treaty member (say, the ECJ) consistently apply, for example, certain WTO provisions in deviation from WTO rulings, or contrary to what another WTO member considers the correct interpretation, such other WTO member can always challenge the national court practice directly before a WTO panel. In the Matthews case, the ECtHR as well has, at least implicitly, expressed a willingness to

\footnotetext{
${ }^{24}$ Jan Wouters and Dries Van Eeckhoutte, Giving Effect to Customary International Law Through European Community Law, K.U. Leuven University, Institute for International Law, Working Paper N. 25 (2002) at 28, with footnote 118 referring to specific cases. See also H.G. Schermers, "European remedies in the field of Human Rights" in C. Kilpatrick, T. Novitz and P. Skidmore (eds.), The Future of Remedies in Europe (Oxford, Hart, 2000) 205, at 205 ("Notwithstanding the absence of any formal binding Treaty commitments, the Court of Justice in fact considered the Community bound by the Convention. For the interpretation of the Convention it takes the interpretation by the European Court of Human Rights into account, and in fact it follows its case-law wherever possible").

${ }^{25}$ See Joost Pauwelyn, The Use of Experts in WTO Dispute Settlement, 51 INTERNATIONAL AND COMPARATIVE LAW QUARTERLY (2002) 325-364.
} 
control the compliance by EC institutions with the ECHR on the premise that EU members, who all ratified the ECHR, cannot evade their obligations through the EC.

In the end, the idea of an organic, interactive dialogue between courts may be too much for traditionally trained European civil lawyers who regard hierarchy and strict divisions of competence as the hallmarks of any legal system worth that name. The approach may be more palatable, though, for common law lawyers. This brings me to the next level of this paper, namely the apparent or real contrast between a European and an American approach to international law and its impact on the unity of international law.

\section{Is There A European And An American Approach To International Law And, If So, Does It Threaten The Unity Of International Law?}

This Section summarizes the conventional view of a stark divide between a European and an American approach to international law. It also offers examples to indicate that this divide may be less severe than usually thought. Most importantly, the Section uses the example of the reception of international law in domestic courts in Europe and the United States to illustrate that transatlantic positions on international law have been, and continue to be, influenced as much by relative power and internal constitutional features that change over time and apply equally across the Atlantic, as by an inherent substantive disagreement between Europe and America on international law. The Section ends with a research agenda to find adequate middle ground between the largely theoretical but analytically useful extremes of a strictly normative approach to international law (European idealism) and a purely transactional view of international law (American realism). 


\section{Conventional wisdom on a European versus an American approach to international law}

Conventional wisdom holds that Europe and the United States have fundamentally different views on international law, what it is and what it can achieve. Whilst European governments agreed to lock themselves into a new EU Constitution, last year Presidential candidates in the United States gained their biggest applause when pledging not to be constrained by the UN or any other "global test". ${ }^{26}$ Europe championed the creation of the ICC and adherence to the Kyoto Protocol, the US continues to object to both. European courts, both in Luxemburg and the member states, have long accepted the idea of referring to foreign and international laws, including the supremacy of EC law. In contrast, the slightest nod to foreign and international norms by American courts is critically received as an abdication of US autonomy. ${ }^{27}$

International legal scholarship is equally divided across the Atlantic. With limited exceptions, European legal scholars approach and analyze international law largely the way they analyze domestic law. They take its independent normative value and

\footnotetext{
${ }^{26}$ For a representative sample, see Robert Kagan, Paradise and Power, America and Europe in the New World Order (2003) and Jeremy Rifkin, The European Dream, How Europe's Vision of the Future is Quietly Eclipsing the American Dream (2004).

${ }^{27}$ See, most eloquently, the dissents by Justice Scalia in Roper v. Simmons ("Though the views of our own citizens are essentially irrelevant to the Court's decision today, the views of other countries and the socalled international community take center stage ... More fundamentally, however, the basic premise of the Court's argument- that American law should conform to the laws of the rest of the world-ought to be rejected out of hand") and Sosa v. Alvarez-Machain ("The notion that a law of nations, redefined to mean the consensus of states on any subject, can be used by a private citizen to control a sovereign's treatment of its own citizens within its own territory is a 20th-century invention of internationalist law professors and human-rights advocates ... We Americans have a method for making the laws that are over us. We elect representatives to two Houses of Congress, each of which must enact the new law and present it for the approval of a President, whom we also elect. For over two decades now, unelected federal judges have been usurping this lawmaking power by converting what they regard as norms of international law into American law"). See also the Bill introduced before the US House of Representatives in March 2004 whose only provision was that

judicial determinations regarding the meaning of the laws of the United States should not be based in whole or in part on judgments, laws, or pronouncements of foreign institutions unless such foreign judgments, laws, or pronouncements are incorporated into the legislative history of laws passed by the elected legislative branches of the United States or otherwise inform an understanding of the original meaning of the laws of the United States $\left(108^{\text {th }}\right.$ Congress, $2 \mathrm{~d}$ Session, H. Res. 568).
} 
constraints for granted and often make abstraction of politics and power. In Europe, the need for cooperation and international governance is a given, the question is only how best to legitimize it. In this exercise many Europeans see the need to "constitutionalize" international law in pursuit of the Kantian ideal of cosmopolitan law separated from politics as far as possible (hence, what I call the European normative approach to international law).

In the United States, in contrast, the academic picture is quite different. With limited exceptions, the debate of whether international law is really law remains as hot as ever. ${ }^{28}$ Most regard international law as merely a pattern of behavior that is driven by selfinterested, rational actors and reflected in law, not constrained by law. ${ }^{29}$ For many American scholars, international law can, at best, be explained as a patchwork of contract-type, cost-benefit analyses aimed at enhancing economic welfare or political support at home. On this view, countries can pick-and-choose from this patchwork depending on the national interest of the day and the "coalition of the willing" which can be found to support it ${ }^{30}$ (hence, what I call the American transactional approach to international law). In this exercise, international cooperation, if feasible and needed in the first place, must be legitimized by national sovereignty, preferably through the interface of domestic, democratic politics. If not, international law is "unacceptable to a free people”. ${ }^{31}$

\section{Counter-examples}

Although the above-explained transatlantic divide over international law surely has truth to it, counter-examples are available. At a most basic level, the claim that "international law is a European tradition” is certainly true when considering its $16^{\text {th }}$ Century founders (such as Grotius) and its subsequent development from the Treaty of Westfalia up to

\footnotetext{
${ }^{28}$ See John Bolton, Is There Really "Law" in International Affairs?, 10 TRANSNATIONAL LAW AND Contemporary Problems 2-48 (2000) and E. Posner, Do States Have A Moral Obligation to Obey International Law? 55 STANFORD JOURNAL OF INTERNATIONAL LAW (2003) 1916.

${ }^{29}$ See supra note 4.

${ }^{30}$ See Richard Pearl, United They Fall, The Spectator, March 22, 2003.

${ }^{31}$ Bolton, supra note 28, at 9.
} 
World War I. Evaluating the 20 ${ }^{\text {th }}$ Century, however, there can be no doubt that the main instigator and staunchest defender of the international system was the United States. Without US leadership, there would not have been a UN, World Bank, IMF or, for that matter, WTO as we now know it.

Evaluating some of the specifics of EC-US positions, within the WTO, for example, European governments have dragged their feet as much (if not more than) the United States when it comes to implementing adverse dispute rulings (consider only the Hormone beef and Bananas disputes). The conduct and tactics of the EC in its relations with potential accession candidates ${ }^{32}$, the countries with which it negotiates association agreements and its former colonies ${ }^{33}$ are, in turn, not that different from those engaged in by the US at a worldwide level, the only difference being that the EC operates from a regional hegemonic position, the US as the world's hegemon.

Equally, although their domestic constitutions point in that direction, domestic courts in Europe have failed to take customary international law seriously and hardly apply it in practice. $^{34}$ More prominently, the ECJ's refusal to give “direct effect” to WTO agreements has been severely criticized by most European law scholars. Some of those scholars have also voiced disagreement with the ECJ's restrictive application of customary international law. ${ }^{35}$

Conversely, if one takes the Bush administration's quest for individual freedom in all corners of the world at face value, it might be mistaken for Kant's liberal theory of

\footnotetext{
${ }^{32}$ See the EC's demand that Croatia hand over suspects to the ICTY before accession talks can start.

${ }^{33}$ See the EC's imposition of counterveiling duties just a few days after it signed the EEA agreement with Austria in Opel Austria; the EC's negotiation of free trade agreements with ACP countries, to replace the Lome Conventions, as well as the EC's new scheme to grant preferences to developing countries (so-called GSP) where extra benefits are conditioned on accession by the developing country concerned to a series of human rights, labor and environmental agreements. All EC association agreements equally have a human rights and democracy clause, conditioning EC benefits to compliance with human rights and democratic values.

${ }^{34}$ See Jan Wouters, Customary International Law before National Courts: Some reflections from a continental European perspective, Non-State Actors and International Law 4:25-38 (2004) (at 25: "When looking into the application given by national courts to customary international law in continental Europe, one cannot escape to find a paradox, namely a remarkable difference between the general rule and its actual application”).

${ }^{35}$ Wouters and Van Eeckhoutte, supra note 24, at 21-22.
} 
international law as, according to one prominent Kantian international lawyer, "Kant includes freedom (respect for individual autonomy under the rule of law) as the first tenet of international ethics". ${ }^{36}$

Equally, any attempt to read beyond the critique of international law in what is now a predominantly hostile US legal academy ${ }^{37}$, shows just how receptive US courts, in particular the US Supreme Court, have been toward foreign and international law. Lawrence v. Texas (2003), for example, declared unconstitutional state laws prohibiting homosexual sodomy, in part, by considering decisions of the European Court of Human Rights. Sosa v. Alvarez-Machain (2004) left the door open for suits by aliens against alien or US individuals or companies based on claims of violation of "a norm of international character accepted by the civilized world and defined with a specificity comparable to the features of the 18th-century paradigms we have recognized [violation of safe conducts, infringement of the rights of ambassadors, and piracy]”. In Simmons v. Roper (2005), the majority cited foreign sources of law - including ICCPR provisions for which the US had tabled an explicit reservation and the Convention on the Rights of the Child that the US did not even ratify! -- as further support for the Court's own views of what punishments violate the Eighth Amendment (“cruel and usual punishments”, in casu the death penalty for anyone under 18 years old). In another instance Bush himself went as far as ordering his native Texan courts to respect the ICJ decision in Avena. ${ }^{38}$ As a recent study on more than 200 years of Supreme Court practice in the area concludes,

\footnotetext{
${ }^{36}$ Fernando R. TESOn, A Philosophy of International LAW (1998) at 3, and also at 7: "The Kantian thesis, then, can be summarized as follows: observance of human rights is a primary requirement to join the community of civilized nations under international law”. Violation of human rights can, in other words, form the basis for intervention into the domestic affairs of another country.

${ }^{37}$ Although surely, Koskenniemi's lament that "[t]he international law professor is an almost extinct species at United States law schools" (see supra note 2, at 117) must be an exaggeration.

${ }^{38}$ If only to subsequently retract from the Vienna Convention's Optional Protocol granting the ICJ jurisdiction over the United States (which, of course, is the US' full right and must therefore be distinguished from the earlier decision to respect US obligations then binding on the US). See George W. Bush, Memorandum for the Attorney General (Feb. 28, 2005): "I have determined ... that the United States will discharge its international obligations under the decision of the International Court of Justice in the [Avena Case], by having state courts give effect to the decision in accordance with general principles of comity in cases filed by the 51 Mexican nationals addressed in that decision”.
} 
the Court's citation of foreign sources of law in recent years is not 'unprecedented' as Justice Scalia implies, but ... citation to foreign sources of law is increasing in the modern era. ${ }^{39}$

Finally, when so-called neo-conservatives in the US make statements such as "claims that 'international law' has binding and authoritative force ultimately ring either hollow or unacceptable to a free people" ${ }^{\text {"40 }}$, are they not taking international law more seriously than traditional European scholars? By raising what are, in my view, valid questions of democratic accountability in the making and enforcement of international law, and in giving unconditional direct effect and supremacy to international law over domestic law, at least those conservative US scholars have realized that modern international law has changed considerably: it really matters (i.e., penetrates the realm of day-to-day domestic affairs) and is for real (e.g., is increasingly enforced). Hence, "a free people" must continuously examine the content and legitimacy of this new, crucial layer of regulation. To stick to the old European normative position that state consent is legally binding (pacta sunt servanda), hence international law must always be complied with, over and above domestic law, under-estimates either the importance and effect of modern international law, or the need for democratic or other legitimizing controls over the lawmaking exercise. Suffice it to point at the popular rejection of the new Constitution for Europe in French and Dutch referenda as proof that this proposition is valid not only in the United States.

3. Might the transatlantic divide be influenced more by relative power and internal constitutional features than by inherent, substantive differences?

That European and American attitudes toward international law are inspired more by temporal elements (such as one's power-position at the time, or the degree of one's constitutional development), witness the striking similarities in both Continents' original

\footnotetext{
${ }^{39}$ Steven G. Calabresi and Stephanie Dotson Zimdah, The Supreme Court and Foreign Sources of Law: Two Hundred Years of Practice and the Juvenile Death Penalty Decision (2005, at 10, on file with the author), adding at 1-2: "The depth of the support for citing foreign sources of law suggests that the movement to do this is just beginning and will only gather force over time. In the wake of Simmons, the debate on the Court is no longer over whether to cite foreign sources of law but over when and how to cite them. This portends a sea change in the Court's doctrine”.

${ }^{40}$ Bolton, supra note 28, at 9 (emphasis added).
} 
position. Indeed, both the founding fathers of the EC and the US expressed very strong commitments to the international legal system.

At the time it was concluded, the Treaty of Rome was after all a treaty part of, and concluded under, international law. Article 300.7 of the EC Treaty confirmed, for the purposes of "domestic" EC law, the binding nature of treaties concluded by the EC with other countries. In early ECJ case law, moreover, the Court granted direct effect to treaties concluded by the EC (Haegeman, 1974 and Kupferberg, 1982) and recognized the supremacy of international treaties over EC and member states' legislation.

In the US, the Supremacy Clause of the Constitution explicitly states that, together with the Constitution itself and US federal law, "all Treaties made, or which shall be made, under the Authority of the United States, shall be the supreme Law of the Land”. This Clause was a sharp departure from the traditionally dualist British position regarding treaties, where treaties did not have the status of municipal law until implemented by statute. In addition, this time in line with English common law, the US also incorporated customary international law as part of the law of the land (now part of so-called federal common law). As Bronckers and Kuijper recently remarked, therefore, at their origin, "[b]oth constitutional systems are monistic". ${ }^{41}$

What explains this concurrence? In my view, it is the fact that, at the time, both the EC and the US were fledgling institutions that were relatively weak and needed to confirm their commitment to the international system, first, to reassure outsiders and, second, to confirm their newly granted powers as against competing domestic actors.

In an attempt to explain the EC's early commitment to international law, Bronckers and Kuijper refer to "positions based on questions of principle and legal reasoning, which were of great importance in giving the relation between Community law and the agreements concluded by the Community a solid legal foundation in a period in which

\footnotetext{
${ }^{41}$ Marco Bronckers and Pieter-Jan Kuijper, The WTO in the European Court of Justice, CMLR (2005, forthcoming).
} 
the Community was still a relatively weak actor on the international stage”. In their view,

Kupferberg was a typical product of a certain period, in which the Community had just started to win its position in international relations ... In such a relatively weak position it is often seen as safest to be closely guided by (international) law. And this seemed all the more obvious, because this was (still) the period in which the Court clearly held a dominant position among the institutions.

Indeed, by giving direct effect and supremacy to treaties concluded by the Community, the ECJ not only increased its own powers. It also elevated the Community institutions as a whole in their power struggle with the member states, especially by highlighting the Community as an actor on the international scene capable of concluding treaties with direct effect and supremacy in the domestic legal systems of the member states.

Explaining, in turn, the US Supremacy Clause, Carlos Vazquez submits that "the repeated violations of treaties by the states [in particular, the Treaty of Peace with Great Britain] was a prime concern of the Framers who gathered in Philadelphia”. He hastens to add, however, that

it was merely one facet of a more general problem: the Articles [of Confederation, preceding the US Constitution] lacked a mechanism for enforcing any of the acts of the central Government, or the Articles themselves. The absence of such a mechanism was a principal reason for the Framers' decision to draft a new Constitution rather than amend the Articles. ${ }^{42}$

In other words, the US Constitution's strong commitment to treaties was inspired, first, by an attempt to impose federal authority over the states and, second, to avert international friction caused by the newly created US, in particular violations of treaties by states which would be attributable to the federal US. ${ }^{43}$

\footnotetext{
${ }^{42}$ Carlos Vazquez, The Four Doctrines of Self-executing Treaties, 89 AJIL (1995), 695, at 698.

${ }^{43}$ See also Lee supra note 7 ("The acute danger to the young, weak Republic's trade and peace posed by individual state defections from U.S. treaties in the late eighteenth century inspired the framers to vest the Supreme Court with this original jurisdiction [over claims by foreign states against states part of the US under international law] despite the possible lack of reciprocity ... It was only in 1934, when America's great-power status in the world balance was incontestable, that the reasons for the Court's original and exclusive jurisdiction over treaty-based suits brought by foreign states against States were completely forgotten”).
} 
In sum, when relatively weak on the international scene and pressed to establish one's powers against competing internal forces, it should come as no surprise that actors strongly commit to international law, first, to gain respect in, and protection from, the international community, second, to utilize the international scene as a platform for the aggrandizement of one's own identity and powers. ${ }^{44}$

Consider how much this situation has changed since those early founding years, both in the EC and in the US.

Summarizing the case law on the question of "direct effect" of WTO law before the ECJ (especially after Portugal v. Commission), Piet Eeckhout concludes that the EC system can now safely be defined as "dualist". ${ }^{45}$ At the same time, the ECJ continues to give direct effect to other treaties, including economic association agreement and preferential agreements such as the Lome Convention. For Bronckers and Kuijper the reasons for this evolution are clear:

it can be questioned, twenty years on [i.e., after Kupferberg in 1982], whether some of these answers [giving direct effect and supremacy to treaties] were not too much focused on matters of principle, and in fact belittled issues that only the larger, more powerful Member States (France!), which were more exposed to international power politics, were aware of ...

\footnotetext{
${ }^{44}$ Note, however, the somewhat contradictory argument that the rejection of international law by the ECJ in certain early cases can be seen as an attempt to distinguish the EC regime from ordinary international law and thereby to confirm the "separate legal order" and identity of the EC. Timmermans, for example, argues that the ECJ's initial reticence to apply customary international law in Dyestuffs (1972) can largely be explained from its efforts to safeguard the autonomy of Community law vis-à-vis international law. See C. Timmermans, "The EU and Public International Law”, 4 European Foreign Affairs Review (1999), 181194, at 181-183. In my view, the force of this argument is rather limited, in particular to the systemic issue of defining the EC treaty as setting up a separate, quasi-domestic legal order (first proclaimed in Van Gendt \& Loos), which is distinct from the substantive question of commitment by the EC to international law. Moreover, the argument does not explain the opposite move in the ECJ's reception of treaties, from Kupferberg's enthusiasm to Portugal v. Commission's skepticism. But see Robert Uerpmann, International Law as an Element of European Constitutional Law: International Supplementary Constitutions, Jean Monnet Working Paper 9/03 (2003) (insisting that recent ECJ case law rejecting direct effect for WTO agreements, and the EC's refusal to ratify the ECHR, are continued attempts to define the identity and autonomy of the EC legal system as against international law).

${ }^{45}$ Piet Eeckhout, External Relations of the European Union, Legal and Constitutional FOUNDATIONS, 302 ff., Oxford: 2004.
} 
All this has now changed. The Community has become an important factor in international relations. Particularly in the WTO, where it was 'present at the creation' and so an 'original Member', it has become a significant power and is also itself better capable of standing up to the power politics of others. Moreover, the Court's position in relation to the other institutions within the Community has changed. In this situation, an adjustment of the Kupferberg case law, particularly regarding the WTO, is understandable and necessary.

Explaining the continued reception of so-called asymmetric treaties (such as the Lome Convention) or closer integration agreements (such as association agreements and FTAs), Rosas refers to the EC's relatively strong power position in these specific treaty settings:

granting the latter types of bilateral agreements direct effect is much easier even if the other Contracting Party does not reciprocate, as first of all it has been the intention of the EU to grant its special partner some specific rights and advantages, and secondly as the EU would in any case have the economic and political means to encourage compliance by the other Contracting Party. ${ }^{46}$

It will not escape the reader that the above power-based positions, as well as the ECJ's own reasons for denying direct effect to WTO law -- based on concerns of internal and external balance of powers, in particular, so as to maintain the scope for manoevre (read: position of power) of the EC executive to delay or negotiate a way out of compliance -are very familiar to any observer of US practice in the field, where deference to the executive and legislature, and questions of sovereignty and democratic legitimacy have long played a predominant role. ${ }^{47}$ Much like Piet Eeckhout in the EC, Curtis Bradley in the US now talks of "our dualist constitution". 48

Indeed, in the US, rather than directly incorporating treaties as the supreme law of the land (as envisaged in the Supremacy Clause), the presumption is now that treaties are not self-executing, if only because in over 90\% of cases the US Executive and/or Congress explicitly deny direct effect when ratifying or implementing the treaty. ${ }^{49}$ The Uruguay

\footnotetext{
${ }^{46}$ See supra note 13 , at 813.

${ }^{47}$ See Andrea Bianchi, International Law and US Courts: The Myth of Lohengrin Revisited, EJIL (2004) 751.

${ }^{48}$ Curtis Bradley, Breard, Our Dualist Constitution, and the International Conception, 51 STANFORD LAW REVIEW 529 (1998-1999).

${ }^{49}$ See Vazquez supra note 42.
} 
Round Agreements Act of 1994, for example, explicitly precludes direct effect of WTO law in US courts. ${ }^{50}$ In a recent Court of Appeals ruling, even the so-called Charming Betsy doctrine of consistent interpretation of US law with international law was put aside. $^{51}$ In addition, customary international law and its reception in domestic US law, traditionally through federal common law, has become a true obsession amongst US international law scholars. ${ }^{52}$ As federal common law normally prevails over inconsistent state law, scholars defending state rights have happily joined the bandwagon against applying customary international law in US courts.

In sum, the reception of international law both in the EC and the US started from strikingly similar (monist-like) positions. Moreover, the current EC and US positions continue to share very similar preoccupations with power relations, sovereignty, democratic legitimacy and balance of powers between the judiciary and the executive/legislature to deny direct effect to international law (both gradually moving to a dualist-type conception). Driving this argument to its extreme, the main difference between them is, in the end, that the EC is powerful in only a limited set of circumstances (in particular external trade, where it denies direct effect), whilst the US speaks from a power position in almost all areas (hence, driving a wedge between international and domestic law in almost all fields). The same power consideration, together with a persisting EC need to confirm its still relatively new powers as against competing internal actors (in particular the member states), might also explain the EC's continued commitment to those areas of international law where the EC remains relatively weak, in particular, treaties outside the trade field (such as the Biodiversity Convention in the

\footnotetext{
${ }^{50}$ URAA 1994 Section 102(c)(1): "No person other than the United States - (A) shall have any cause of action or defense under any of the Uruguay Round Agreements or by virtue of congressional approval of such an agreement, or (B) may challenge, in any action brought under any provision of law, any action or inaction by any department, agency, or other instrumentality of the United States, any State, or any political subdivision of a State on the ground that such action or inaction is inconsistent with such agreement". See John Barcelo, The Status of WTO Rules in Domestic Law - An American Perspective, draft, June 2004 (on file with the author).

${ }^{51}$ Corus Staal v. Department of Commerce, US Court of Appeals for the Federal Circuit, 04/1107, December 21, 2004.

${ }^{52}$ Starting with C. Bradley and J. Goldsmith, Customary International Law as Federal Common Law: A Critique of the Modern Position, HARVARD LAW REVIEW 110:815.
} 
Biotech Inventions case) and (albeit with limitations) customary international law (in Racke and Opel Austria).

Put differently, when Europe talks of its commitment to international law, or heralds the supremacy and direct effect of international law, it may partly be doing so based on its normative, idealist approach to international law. However, another explanatory factor is that Europe speaks from a position of relative weakness and is, therefore, quite keen to see everyone (including its more powerful partners) commit to international constraints. ${ }^{53}$ In addition, as the EC is not a sovereign state but remains an international institution with strict internal controls by its member states also when the EC operates externally, for the EC to commit itself even to WTO constraints (where the EC does speak from a powerful position) is relatively easy: as the EC is already committed to principles of transparency and non-discrimination through its internal structure, it is easier to accept the same constraints as they are imposed from Geneva, especially if it means that the EC’s trading partners will do the same and thus operate from an equal level playing field. ${ }^{54}$

\footnotetext{
${ }^{53}$ For elements of European weakness even in the field of trade (thus partly explaining the EC's commitment to, for example, the strengthened dispute process of the WTO), see Theofanis Christoforou and Allan Rosas, A preliminary assessment of nearly ten years of participation by the European Union in the WTO dispute settlement system, on file with the author:
}

The EC, despite the fact that it enjoyed at that time exclusive competence in external trade ... has not always been capable, from a structural and internal organizational point of view, of exploiting effectively this power, especially when countermeasures and retaliatory action were contemplated ... EU action in the external trade field is, more frequently than not, based on the lowest common denominator of the positions expressed by the Member States or it takes a considerably long period of time to be framed and adopted. Powerful third countries, like the US, could fairly easily apply the "divide and rule" strategy to bring standstill in, and even destroy the cohesion of, the decision-making process in the Council.

${ }^{54}$ See Christoforou and Rosas (ibid.):

issues of transparency, legitimacy and good governance are raised quite frequently and with even more rigor against trade measures and actions proposed by the European Commission for adoption by the EU ... There is little doubt, therefore, that these internal structural and organizational problems have played and still continue to play a prominent role in constraining EU's behavior internationally ... It appears, therefore, that for the EU, in order to be able to complete effectively its mission internally and still be an efficient international player, there was a greater need to rely more frequently on consensual policy making and the rule of law. This is considered necessary in order to balance the divergent trade and economic interests and rally the support of its Member States, as it cannot apply in its internal decision-making process pure power politics. In other words, the EU was and still is in a much greater need of an international trade regime that is based on principles, norms, rules, and judicial supervision, for both internal and external legal reasons, than individual nation states. 
Conversely, in the United States power relations and domestic sovereignty are not the only factors at play. In the US, much like in Europe, a prominent place remains reserved for normative impulses and value-laden references to, for example, the ideal of individual freedom or the international community (as in recent US Supreme Court rulings referring to, for example, "norms of international character accepted by the civilized world"55 or Bush’s reference in the Avena determination to "general principles of comity”).

In short, Europe and the United States play the same game, within the same framework and with the same reflexes. Differences in their position have to do more with relative strength and constitutional framework, than substantive transatlantic disagreements.

\section{The search for a middle ground between the normative European and the transactional American approach: a research agenda}

The previous section illustrates that, though theoretically appealing, the divide between European idealism (normativism) and American realism (transactionalism) is less outspoken in practice. Europe has demonstrated a healthy dose of realism itself (witness, in particular, the ECJ case law on the effect of WTO law), and the US is not, and has never been, an antithesis to international law (witness its historical role since World War II, the surge of references to international law by the US Supreme Court and the Bush foreign affairs agenda centered around Kantian ideals of freedom).

Nonetheless, the juxtaposition of a European and an American approach to international law remains analytically useful. It can serve as a framework within which to critically assess the two extremes of idealism and realism and to find a balanced middle ground between them.

\footnotetext{
${ }^{55}$ Sosa v. Alvarez-Machain.
} 
Consider, for example, the risk of inconsistent interpretations discussed in Section II. The normative European approach validly raises this concern (a non-issue in American transactionalism). Yet, the normative approach may go too far and sacrifice a less than homogenous application of international law only to safeguard the system's sacred unity and hierarchical relation to domestic legal systems. American transactionalism - in particular, concepts such as "regulatory competition" - can temper this extreme and lead to the proposals suggested in this paper centered around the notion of judicial tolerance. Equally, the question of whether to give direct effect to international law, discussed in Section III, would receive a resounding yes under the European normative extreme: international law is legally binding, so what is the problem with giving effect to it in domestic courts? Such principled position - though raising valid points of moral commitment and legal predictability - must, however, be tempered by the democratic legitimacy and balance of powers concerns of the transactional, American approach to international law. This should happen, however, without falling into the extreme of this transactional approach (such as construing international and domestic law as hermetically sealed-off compartments or denying any legally binding effect to international law).

This research agenda is, in my view, one of the greatest challenges for us international lawyers in the $21^{\text {st }}$ century. Rather than threatening the unity of international law, it is absolutely necessary to pursue this agenda - including a more outspoken European agenda - to preserve the long-term integrity of the international legal system. As AnneMarie Slaughter put it in 2002:

If the U.S. can recognize that international law does have a crucial role to play and the EU can recognize that many traditional international rules and institutions must now be modernized, they have a tremendous opportunity to work together to strengthen the global legal order. ${ }^{56}$

\footnotetext{
${ }^{56}$ Anne-Marie Slaughter, The Future of International Law: Ending the US-Europe Divide, Crimes of War Project, September 2002, available at http://www.crimesofwar.org/sept-mag/sept-home.html.
} 


\section{Conclusions}

The application of international law by domestic courts does not threaten the unity of international law. The risk of inconsistent interpretations, or one national court applying international law inconsistently with other national courts or the relevant international tribunal, is not a reason to deny application of international law before domestic courts. There may be other reasons to do so, based on democratic legitimacy, internal balance of powers or reciprocity with other nations. Yet, the risk of fragmentation or inconsistent interpretations is not one of them.

From the perspective of international law, the risk of inconsistent interpretations is far outweighed by the benefits of a more effective international law. In addition, it may have a bright side, namely the refinement and further development of international law through “judicial competition”. The multitude of layers and concerns raised by today’s format of international governance are too complex to be constrained in strict hierarchies and preliminary reference schemes. Instead, judicial curiosity, dialogue and tolerance are the best recipe to nurture the integrity and further development of international law.

Courts can, in particular, avoid inconsistent interpretations by referring to the rulings of international tribunals and requesting expert advice from international organizations. Moreover, when serious inconsistencies do persist, other treaty parties can challenge the national court practice before the relevant international tribunal. Calls for either strict unity (for example, to reserve WTO interpretations to the WTO level alone) or selfcontained fragmentation (for example, for the ECJ or WTO panels to reject any reference to international law allegedly to maintain their autonomy) can easily be reduced to hegemonic projects.

In turn, the definition and pursuit of a European agenda or European approach to international law does not threaten the unity of international law. Rather than negative attacks on how other nations (read: the United States) should not approach international law, Europe must offer its own, positive agenda on how to view and refine the 
international system. Europe must shed its reluctance to define, and aggressively pursue, this agenda based on European values and interests. Doing so will remind everyone how much Europe and America continue to have in common. Indeed, when scratching the surface of today's conventional wisdom of Europe as the defender of international law and America as its antithesis, the attitudes, mental framework and reflexes as well as prevailing concerns are strikingly similar across the Atlantic. Both countries, in particular, have strongly committed to international law when relatively weak on the international scene and pressed to establish their powers against competing internal forces, first, to gain respect in, and protection from, the international community, second, to utilize the international scene as a platform for the aggrandizement of their own identity and powers. Most differences in approach are, therefore, explained not by inherent, substantive disagreements between Europe and the US, but rather by relative power positions and internal constitutional features.

Given those transatlantic similarities, one of the greatest challenges for us international lawyers in the $21^{\text {st }}$ Century will be to unearth these convergences and to find answers to the common questions of, for example, the democratic accountability and legitimacy of international law raised both in Europe and the US. This requires an appraisal of both the extremes of what I called the strictly normative approach to international law (European idealism) and the purely transactional view of international law (American realism). Yet, to maintain the long-term integrity of international law what is needed is a balanced middle ground between those two extremes. 